\title{
Healthy and Balanced Nutrition for Children through Physical Education Classes
}

\author{
Rubén Trigueros ${ }^{1, * \mathbb{D}}$, Sergio González-Bernal ${ }^{2}$, Jerónimo J. González-Bernal ${ }^{2} \mathbb{D}$, \\ Raquel de la Fuente-Anuncibay ${ }^{2}$ and José M. Aguilar-Parra ${ }^{1, *}$ \\ 1 Hum-878 Research Team, Health Research Centre, Department of Psychology, University of Almería, \\ 04120 Almería, Spain \\ 2 Department of Psychology, University of Burgos, 09001 Burgos, Spain; sbernall@ubu.es (S.G.-B.); \\ jejavier@ubu.es (J.J.G.-B.); raquelfa@ubu.es (R.d.l.F.-A.) \\ * Correspondence: rtr088@ual.es (R.T.); jmaguilar@ual.es (J.M.A.-P.)
}

check for

updates

Citation: Trigueros, R.;

González-Bernal, S.; González-Bernal,

J.J.; Fuente-Anuncibay, R.d.l.;

Aguilar-Parra, J.M. Healthy and

Balanced Nutrition for Children through Physical Education Classes. Life 2021, 11, 678. https://doi.org/ 10.3390/life11070678

Academic Editors: Giacomo Biasucci and Elvira Verduci

Received: 18 June 2021

Accepted: 9 July 2021

Published: 11 July 2021

Publisher's Note: MDPI stays neutral with regard to jurisdictional claims in published maps and institutional affiliations.

Copyright: (c) 2021 by the authors. Licensee MDPI, Basel, Switzerland. This article is an open access article distributed under the terms and conditions of the Creative Commons Attribution (CC BY) license (https:// creativecommons.org/licenses/by/ $4.0 /)$.

\begin{abstract}
Introduction. In recent years, the rate of childhood obesity has been on the rise, currently standing at levels close to $20 \%$. This means that one in five children is more likely to suffer from cardiovascular or metabolic diseases. Physical Education classes are therefore an ideal way to raise awareness among children and their families about healthy and balanced eating habits. Method. A total of 113 primary school students, aged 9-12 years, participated in the study. In order to analyze the data, a structural equation model (SEM) was used to analyze the influence between the variables. Results. The SEM results revealed that a controlling social context showed a negative prediction of psychological need satisfaction and a positive prediction of frustration. However, an autonomy supportive social context showed a negative prediction of psychological need satisfaction and a positive prediction of psychological need satisfaction. Frustration of psychological needs was negatively related to motivation, whereas satisfaction was positively related to motivation. In turn, motivation was positively related to each of the factors of the theory of planned behaviour. Finally, intention to follow a healthy diet was positively related to the Mediterranean diet. Discussion. These results revealed the importance of social context and physical education classes in the adoption of a balanced diet.
\end{abstract}

Keywords: Mediterranean diet; school; self-determination; physical education; theory of planed behaviour

\section{Introduction}

According to the latest report of the Spanish Society of Cardiology, nearly $38 \%$ of Spanish children aged 6-12 years are obese or overweight [1,2]. In addition, abdominal obesity affects three out of ten children, especially boys [1]. These data reflect a clear increase in childhood obesity rates in Spain in recent years, see [3,4]. In this sense, childhood overweight and obesity are associated with a higher probability of becoming obese adults and with a higher risk of suffering from diseases, such as type 2 diabetes, cardiovascular disease or certain types of cancer in adulthood [5,6]. For this reason, Physical Education (PE) classes can play a fundamental role in promoting healthy lifestyle habits, as their objectives include healthy and balanced nutrition and the adoption of active habits during leisure time [7]. In addition, the influence of parents and teachers on the dietary behaviour and physical exercise of young people is fundamental [8].

There are several theories that have analyzed human behaviour, among them, the SelfDetermination Theory (SDT) $[9,10]$. This theory states that the social context (e.g., teachers, parents, etc.) exerts a very important influence on the individual's behaviors, which can be through two very different styles: autonomy supportive and controlling [11,12]. Autonomy support refers to the social context promoting the individual's mental and physical development through personal initiative $[13,14]$. In contrast, the controlling style promotes the physical and mental development of the individual but based on the use of 
coercive means and external pressures, which prevents personal initiative $[13,14]$. These interpersonal styles exert a very important influence on the satisfaction or frustration of basic psychological needs, which are basically internal psychological nourishments, present in all human beings, and which are necessary for the correct social and psychological development and well-being of people $[15,16]$. Thus, those people who perceive autonomy in their decision-making, competency in their actions and support and integration in their social reference group will feel a satisfaction of their psychological needs [16], which is related to commitment and permanence in the activity [17]. However, if people experience a feeling of abandonment, low success in their actions and a lack of decision-making, they will experience a frustration of their psychological needs [16,17], which is related to disengagement and disengagement $[16,17]$. Thus, those who experience frustration of their own psychological needs will show a greater predisposition towards controlled motivation and even demotivation [18]. On the other hand, those who have their psychological needs satisfied will show a greater predisposition towards autonomous motivation [19].

Studies focusing on self-determination theory at the primary school stage are certainly scarce. However, it is a stage that is fundamental in the adoption of habits during adolescence and adulthood [20]. Among the studies that have analyzed the basic psychological needs and motivation of students at the primary school stage, the one by Van-Aart, Hartman, Elferink-Gemser, Mombarg and Visscher [21], which showed positive predictability between satisfaction of basic psychological needs and intrinsic motivation, stands out in relation to Physical Education classes. Similarly, a study by Patón, Fernández and Nemiña [22] showed the positive correlation between basic psychological needs satisfaction and motivation and these, in turn, with students' enjoyment and involvement during PE lessons. However, these studies focusing on the primary school stage have not analyzed the effect of the social context (parents and teachers) on basic psychological needs, despite the influence they exert on children's behavioral patterns. Similarly, these studies have not taken into consideration the effect of frustration of students' basic psychological needs on motivation nor have they taken into account students' behavioral patterns in relation to the basic objectives of the area of PE.

The Theory of Planned Behaviour (TPB) is one of the main theoretical models that tries to explain the predictive behavioral character of decision-making $[23,24]$. In this sense, this theory refers to the systematic use that people make of information and consideration of the consequences of their actions before carrying them out. Thus, the immediate determinant of behaviour is the intention to perform it, which is determined by three components: attitude towards the behaviour, which refers to the set of beliefs about the outcome of the behaviour and the valuation of such outcomes; subjective norms, which refer to normative beliefs about whether or not the behaviour should be performed and the motivation to comply with such pressures; finally, the perception of behavioral control, which refers to whether the person has all the power to make decisions and act accordingly in a given situation [25,26]. Thus, for an individual to develop a certain behaviour, it is necessary that he or she has a positive attitude towards the behaviour, valuing positively the state of well-being that it generates. In addition, the social context closest to the individual must positively promote this type of behaviour and even display valuable and positive attitudes, and furthermore, the person must be in control at all times of the behaviour that he or she is developing [27].

Despite the importance that the Theory of Planned Behaviour may have in helping to understand the development and establishment of young people's behaviors, we have no evidence of studies during the Primary Education stage, although we do have evidence of studies at the Secondary Education stage. In this regard, several studies have shown how the Theory of Planned Behaviour has been positively related to behaviors related to physical activity habits [27-29] and balanced eating habits [30,31] and negatively related to maladaptive habits, such as cigarette smoking [32].

Thus, the present study aimed to analyze the influence of social context (parents and teachers) on basic psychological needs (frustration and satisfaction), motivation towards 
PE classes, attitude, subjective norms and behavioral control, eating habits intention and Mediterranean diet. The following hypotheses were proposed: (1) A social context (parents and teacher) that promotes autonomy support will positively predict psychological need satisfaction and negatively predict psychological need frustration. In contrast, a social context (parents and teacher) that promotes a controlling style will positively predict psychological need frustration and negatively predict psychological need satisfaction. (2) Satisfaction of psychological needs will positively predict motivation towards PE classes. In contrast, frustration of psychological needs will negatively predict motivation towards PE classes. (3) Motivation towards PE classes will positively predict subjective norms, attitude and behavioral control, which, in turn, will positively predict intention to maintain healthy eating habits. (4) Finally, intention will predict Mediterranean diet.

\section{Materials and Methods}

\subsection{Participants}

The number of primary school students who decided to participate in the study was 1113 (511 boys and 602 girls), aged between 9 and 12 years old $(M=10.78 ; S D=0.66)$. The students were enrolled in different schools in the province of Burgos (Spain). Of the participants in the study: 671 were in public schools, 262 were in private schools and 180 were in state schools.

\subsection{Measurements}

Scale of Perceived Teacher Support [27]. It is a Likert-type scale (from 1 (strongly disagree) to 7 (strongly agree)) with two factors: autonomy support (12 items) and psychological control (7 items). This scale assesses, from the student's perspective, perceived teacher support and control.

Scale of Perceived Support by Parents [27]. This is a Likert-type scale (from 1 (strongly disagree) to 7 (strongly agree)) with two factors: autonomy support (12 items) and psychological control (7 items). This scale assesses, from the student's perspective, perceived parental support and control.

Scale of Basic Psychological Needs Satisfaction in Physical Education [33]. This is a Likert-type scale (from 1 (strongly disagree) to 7 (strongly agree)) with four factors: competence (4 items), autonomy (4 items), novelty (6 items) and relatedness (4 items). This scale assesses, from the student's perspective, basic psychological needs satisfaction in PE.

Scale of frustration of basic psychological needs in physical education [34]. It is a Likert-type scale (from 1 (strongly disagree) to 7 (strongly agree)) with four factors: competence (4 items), autonomy (4 items), novelty (5 items) and relatedness (4 items). This scale assesses, from the student's perspective, basic psychological needs frustration in PE.

Motivation in physical education. The Spanish version is used to analyze student motivation [35]. The scale is a Likert-type scale (from 1 (not true) to 7 (completely true)) with six factors: intrinsic motivation (4 items), integrated regulation (4 items), identified regulation (4 items), introjected regulation (4 items), external regulation (3 items) and amotivation ( 4 items). This scale assesses, from the student's perspective, the motivation in physical education classes.

Social cognition and intention: The scale from the TPB, which has been used successfully in several studies [30,31], was used. The scale consists of four factors: subjective norm, intention, perceived behavioral control and attitude. The responses given by the students were on a Likert-type scale (strongly disagree (1) to strongly agree (7)), except for one item of the subjective norm factor (no control (1) to strong control (7)). This scale assesses, from the students' perspective, their future behavioral predisposition towards balanced eating.

Balanced diet: The Spanish version of the scale linked to the Mediterranean diet [36] was used. This scale consists of 16 items, with an overall score ranging from 0 to 12 . 


\subsection{Procedure}

Before starting the study, contact was made with the Bioethics Committee of the University of Almeria in order to obtain its approval. Once approval was obtained (Ref. UALBIO 2020/008), the management teams of various educational centers were contacted in order to obtain their collaboration in order to carry out the study and to inform them of the objectives of the study. Subsequently, contact was established with the students of the educational centers to request their participation in the study, for which they had to provide informed consent, detailing the objectives of the study, signed by the parents or legal guardians. The questionnaires were completed individually and on paper at the beginning of the PE lessons. In addition, a member of the research group was present to answer any questions from the participants.

The completion of the questionnaires took around $25 \mathrm{~min}$, and all ethical procedures established in the Helsinki Declaration were respected at all times.

\subsection{Data Analysis}

In order to achieve the objectives of the study, several statistical analyses were necessary. First, the data were analyzed descriptively, calculating mean standard deviation and bivariate correlations. Subsequently, the reliability of the Cronbach's Alpha, Omega coefficient and AVE factors were analyzed (Table 1). Finally, structural equation modelling was carried out in order to analyze the predictive relationships between the study factors. The statistical programs SPSS v25 and AMOS v22 were used for these analyses.

The hypothesized model (Figure 1) was analyzed using the maximum likelihood method, as it takes into account the non-normal distribution of the data and is also the most suitable for Likert scales [37]. Next to the maximum likelihood method, a bootstrapping of 6000 interactions was used [38]. The following fit indices were used to define the model as good [39]: the Root Mean Square Error of Approximation (RMSEA), with its $90 \%$ confidence interval (CI), should have been found with values below 0.06 , indicating an adequate and excellent fit. The incremental CFI (Comparative Fit Index), IFI (Incremental Fit Index) and TLI (Tucker-Lewis Index) with values above 0.95 were also considered adequate and excellent indices. The $\chi 2 / \mathrm{df}$ index was considered adequate and excellent when it was between 2 and 3. Finally, the SRMR (Standardized Root Mean Square Residual) with values below 0.08 was also considered adequate and excellent. 
Table 1. Descriptive statistics, internal consistency analysis and bivariate correlations.

\begin{tabular}{|c|c|c|c|c|c|c|c|c|c|c|c|c|c|c|c|}
\hline Factors & $M$ & $S D$ & $\alpha$ & $\omega$ & AVE & 1 & 2 & 3 & 4 & 5 & 6 & 7 & 8 & 9 & 10 \\
\hline 1. Autonomy Support (Parents) & 5.31 & 1.11 & 0.88 & 0.89 & 0.66 & & $-0.33^{* *}$ & $0.41^{* * *}$ & $-0.21^{* *}$ & $0.42^{* * *}$ & $0.31^{* *}$ & $0.25 * *$ & $0.22 * *$ & $0.32 * *$ & $0.59^{* *}$ \\
\hline 2. Psychological Control (Parents) & 2.12 & 1.03 & 0.83 & 0.85 & 0.69 & & & $-0.39 * *$ & $0.55^{* * *}$ & $-0.33^{* *}$ & $-0.19 *$ & $-0.14^{* *}$ & $-0.38^{* *}$ & -0.24 * & $-0.12^{* *}$ \\
\hline 3. Autonomy Support (Teacher) & 5.40 & 1.15 & 0.81 & 0.83 & 0.68 & & & & $-0.30 *$ & $0.49^{* * *}$ & $0.28 * *$ & $0.28 * *$ & $0.32 * *$ & $0.33^{* *}$ & $0.45^{* *}$ \\
\hline 4. Psychological Control (Teacher) & 2.07 & 1.04 & 0.84 & 0.85 & 0.71 & & & & & $-0.29 * *$ & $-0.39 * *$ & $-0.30 *$ & $-0.20 * *$ & -0.23 * & $-0.26^{* *}$ \\
\hline 5. Motivation in PE & 16.61 & 7.32 & - & & - & & & & & - & $0.44^{* * *}$ & $0.51^{* *}$ & $0.37^{* *}$ & $0.38^{* *}$ & $0.37^{* *}$ \\
\hline 6. Attitude & 5.11 & 1.88 & 0.80 & 0.82 & 0.72 & & & & & & - & $0.43 * *$ & $0.40^{* * *}$ & $0.52 * *$ & $0.58^{* *}$ \\
\hline 7. Behavioural Control & 4.33 & 1.33 & 0.82 & 0.83 & 0.64 & & & & & & & - & $0.45^{* * *}$ & $0.60^{* * *}$ & $0.61^{* *}$ \\
\hline 8. Subjective Norms & 5.02 & 1.72 & 0.86 & 0.87 & 0.69 & & & & & & & & - & $0.52^{* *}$ & $0.47^{* * *}$ \\
\hline 10. Mediterranean Diet & 7.83 & 1.01 & 0.83 & 0.86 & 0.66 & & & & & & & & & & - \\
\hline
\end{tabular}

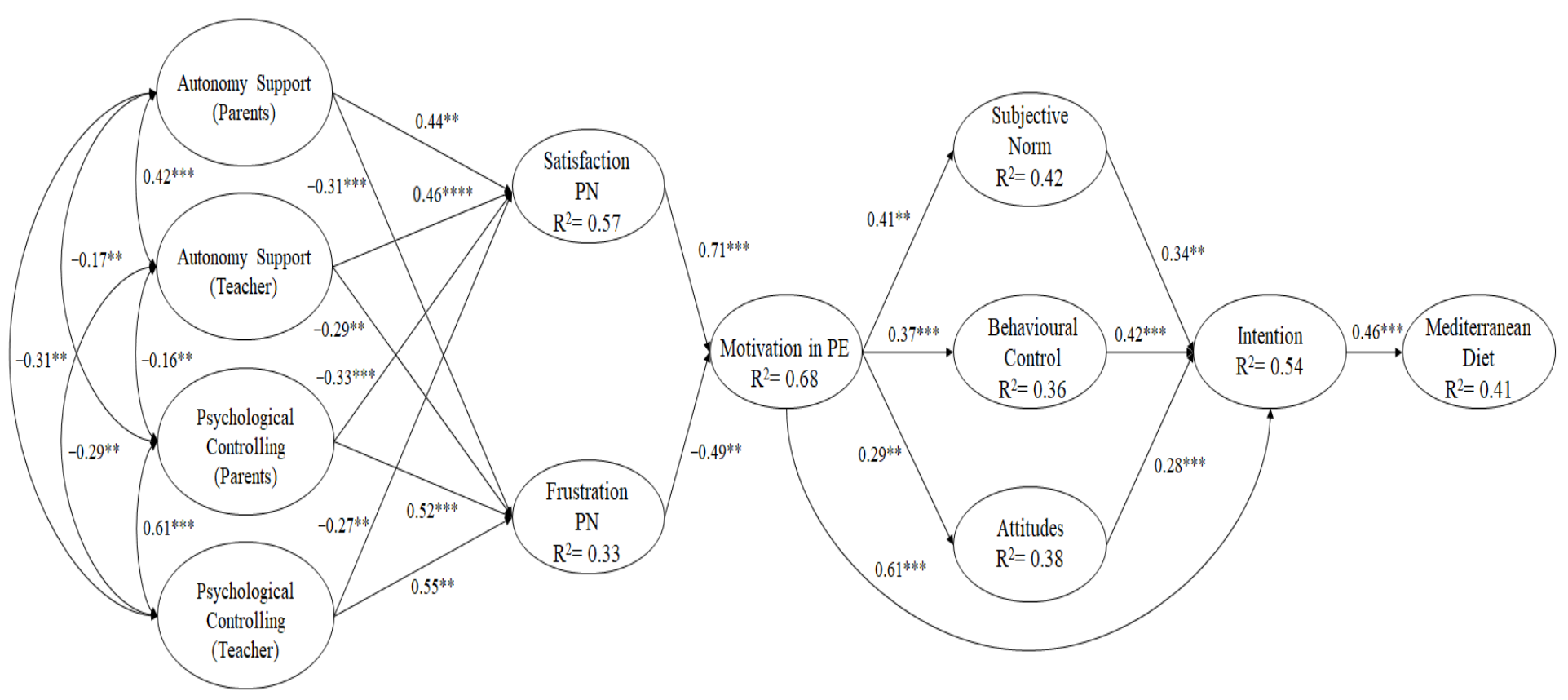

Figure 1. Structural Equation Model. Note: ${ }^{* *} p<0.01,{ }^{* * *} p<0.001,{ }^{* * * *} p<0.0001$. 


\section{Results}

\subsection{Descriptive Statistics, Reliability Analysis and Bivariate Correlations}

Table 1 shows the descriptive statistics, bivariate correlations and reliability analysis. The correlations showed a positive score between those factors that showed a closer relationship, while those factors that were more distant showed a negative correlation. Reliability analysis through Cronbach's alpha and the Omega coefficient showed a score above 0.70 . In terms of discriminant validity (AVE), the score was above 0.60 , reflecting the non-existence of overlap between the factors.

\subsection{Structural Equation Model Analysis}

The hypothesized models (Figure 1) tested through structural equation modelling were adequate: $\chi^{2}(301, n=1113)=867.78, \chi^{2} / \mathrm{df}=2.88, p<0.001, \mathrm{TLI}=0.96, \mathrm{IFI}=0.96, \mathrm{CFI}=0.96$, RMSEA $=0.063$. (IC 90\% $=0.057-0.069)$, SRMR $=0.051$. The predictive relationship between each of the factors was examined through standardized regression weights, the results of which are as follows.

(1) Teacher-perceived interpersonal control style showed positive effects on psychological need frustration $(\beta=0.55, p<0.01)$ and negative effects on basic psychological need satisfaction $(\beta=-0.27, p<0.01)$. In contrast, teacher autonomy support showed positive effects on basic psychological need satisfaction $(\beta=-0.29, p<0.01)$ and negative effects on psychological need frustration $(\beta=0.46, p<0.001)$.

(2) Parental-perceived interpersonal control style showed positive effects on psychological need frustration $(\beta=0.44, p<0.01)$ and negative effects on basic psychological need satisfaction $(\beta=-0.31, p<0.001)$. In contrast, parental autonomy support showed positive effects on basic psychological need satisfaction $(\beta=0.52, p<0.01)$ and negative effects on psychological need frustration $(\beta=-0.33, p<0.001)$.

(3) Frustration of psychological needs showed negative effects on motivation towards PE classes $(\beta=-0.49, p<0.01)$. However, satisfaction of psychological needs showed positive effects on motivation towards PE lessons $(\beta=0.71, p<0.001)$.

(4) Motivation towards PE classes showed positive effects on attitudes $(\beta=0.29$, $p<0.01)$, behavioral control $(\beta=0.37, p<0.001)$, subjective norms $(\beta=0.41, p<0.01)$ and intention $(\beta=0.61, p<0.001)$.

(5) Intention to follow a healthy and balanced diet was positively predicted by attitudes $(\beta=0.28, p<0.001)$, behavioral control $(\beta=0.42, p<0.001)$ and subjective norms $(\beta=0.34$, $p<0.01)$.

(6) Intention to follow a healthy and balanced diet showed positive effects on the Mediterranean diet $(\beta=0.46, p<0.01)$.

\section{Discussion}

The present study aimed to analyze the influence of parents and the PE teacher on the basic psychological needs, motivation and intentional eating habits of school-aged children. In this sense, PE classes are a discipline that can be fundamental in order to strengthen future adaptive behaviors related to healthy and balanced eating [40-42]. However, the studies in the field of Primary Education are certainly laconic, focusing mainly on the effect of satisfying the psychological needs and motivation of students on the classroom climate (e.g., fun, boredom, etc.), ignoring the instrumental objective of the subject. In this sense, it is in childhood that many of the behaviors that will take place during adolescence and adulthood are established, which is why the present study focused on this stage [43].

The results of the study showed how the social context exerts a significant influence on the satisfaction and frustration of basic psychological needs, in such a way that support for autonomy has been positively related to satisfaction and negatively related to frustration, with psychological control being the opposite. These results are in accordance with the postulates of SDT [16] and with the results achieved in several studies in the context of Secondary Education [44,45], since in Primary Education, there is no evidence of these relationships presented in the present study. Thus, the results presented here highlight 
the negative influence that the social context can have on the perceptual development of the environment and the psychological development of young people [46]. It is therefore necessary to create a positive classroom climate based on personal introspection and less on external demands and pressures [47].

On the other hand, basic psychological needs were positively related to motivation, whereas psychological need frustration had a negative influence on motivation. These results are similar to several studies in the context of primary education, but only taking into account the variables of psychological need satisfaction and motivation [21,22]. However, in the context of Secondary Education, there are several studies that endorse the results achieved in the present study [47-49]. In this sense, a study conducted by Trigueros and Navarro [50], with secondary school students aged 12-16 years, showed that satisfaction of psychological needs positively predicted motivation, while frustration exerted a negative influence. These results are in line with the postulates of SDT [16], endorsing that if students are presented with achievable challenges, have a good classroom climate and have room for self-decision, they will be more receptive and involved in classroom dynamics [17].

In addition, the results showed that motivation towards PE lessons was positively related to attitude, subjective norms, behavioral control and intention, and this, in turn, was positively related to Mediterranean diet. It is difficult to compare these results with studies in primary education. However, at the secondary school level, studies have shown that a high internal motivation towards PE classes is positively related to attitude, intention to be physically active and adopting a positive predisposition towards the Mediterranean diet as a result of a positive mental representation of the Mediterranean diet. In this sense, a study conducted by Lirola et al. [51] in a population of adolescents showed how motivation towards PE classes has a positive influence on attitude, behavioral control and subjective norms, favoring healthy and balanced eating. In the same way, but with regard to the practice of physical activity, a study carried out in a population of adolescents by Trigueros et al. [8] analyzed how motivation towards PE classes was positively related to attitude, behavioral control and subjective norms, and, in turn, attitude, behavioral control and subjective norms showed a positive relationship with regard to the intention to practice PA.

However, the results achieved in the present study are not without a number of limitations: (a) the use of self-reported questionnaires severely limited the information to be captured, although it allowed for a greater amount of information to be collected from several subjects; (b) the population participating in the study came from the same geographical location, which limits the overall representativeness of the participants; (c) the present study ignored the influence of other factors, such as emotional factors, which play a fundamental role in the adoption of behaviour. In this sense, emotions play a precursor role to motivation in judging the facts of the environment.

\section{Conclusions}

The results shown in this study confirm the clear reciprocity between SDT and TPB. In this way, the influence of the social context is key in the perceptual-psychological development of young people and in the reinforcement of behaviurs related to the healthy and balanced diet that the Mediterranean diet represents.

Author Contributions: Conceptualization, R.T. and J.J.G.-B.; methodology, J.M.A.-P.; formal analysis, R.T.; investigation, J.J.G.-B.; resources, J.M.A.-P.; data curation, S.G.-B. and R.d.l.F.-A.; writingoriginal draft preparation, R.T.; writing-review and editing, J.M.A.-P.; visualization, J.J.G.-B.; supervision, R.T.; project administration, R.T.; funding acquisition, J.J.G.-B. All authors have read and agreed to the published version of the manuscript.

Funding: This research received no external funding.

Institutional Review Board Statement: The study was conducted according to the guidelines of the Declaration of Helsinki and approved by Bioethics Committee of University of Almería (Ref. UALBIO 2019/008). 
Informed Consent Statement: Informed consent was obtained from all subjects involved in the study.

Data Availability Statement: Not applicable.

Conflicts of Interest: The authors declare no conflict of interest.

\section{References}

1. Aranceta-Bartrina, J.; Gianzo-Citores, M.; Pérez-Rodrigo, C. Prevalencia de sobrepeso, obesidad y obesidad abdominal en población española entre 3 y 24 años. Estudio ENPE. Rev. Española Cardiol. 2020, 73, 290-299. [CrossRef]

2. Caixàs, A.; Villaró, M.; Arraiza, C.; Montalvá, J.C.; Lecube, A.; Fernández-García, J.M.; Corio, R.; Bellido, D.; Llisterri, J.L.; Tinahones, F.J. Documento de consenso de la Sociedad Española de Obesidad (SEEDO) y de la Sociedad Española de Médicos de Atención Primaria (SEMERGEN) sobre la continuidad asistencial en obesidad entre Atención Primaria y Unidades Especializadas Hospitalarias 2019. Med. Clín. 2020, 155, 267.e1-267.e11. [CrossRef] [PubMed]

3. Gómez, J.C.; Ena, J.; Lorido, J.A.; Ripoll, J.S.; Carrasco-Sánchez, F.J.; Gómez-Huelgas, R.; Soto, M.P.; Lista, J.D.; Martínez, P.P. La obesidad es una enfermedad crónica. Posicionamiento del grupo de trabajo de Diabetes, Obesidad y Nutrición de la Sociedad Española de Medicina Interna (SEMI) por un abordaje centrado en la persona con obesidad. Rev. Clín. Española 2020. [CrossRef]

4. Serra Majem, L.; Ribas Barba, L.; Aranceta Bartrina, J.; Pérez Rodrigo, C.; Saavedra Santana, P.; Peña Quintana, L. Obesidad infantil y juvenil en España. Resultados del Estudio enKid (1998-2000). Med. Clín. 2003, 121, 725-732. [CrossRef]

5. Bocharova, O.V.; Teplyakova, E.D. Children and adolescents' obesity is the 21st century health problem. Kazan Med. J. 2020, 101, 381-388. [CrossRef]

6. Cali, A.M.; Caprio, S. Obesity in children and adolescents. J. Clin. Endocrinol. Metab. 2008, 93 (Suppl. S11), s31-s36. [CrossRef]

7. Pope, Z.C.; Barr-Anderson, D.J.; Lewis, B.A.; Pereira, M.A.; Gao, Z. Use of wearable technology and social media to improve physical activity and dietary behaviors among college students: A 12-week randomized pilot study. Int. J. Environ. Res. Public Health 2019, 16, 3579. [CrossRef]

8. Trigueros, R.; García-Tascón, M.; Gallardo, A.M.; Alías, A.; Aguilar-Parra, J.M. The influence of the teacher's prosocial skills on the mindwandering, creative intelligence, emotions, and academic performance of secondary students in the area of physical education classes. Int. J. Environ. Res. Public Health 2020, 17, 1437. [CrossRef]

9. Ryan, R.M.; Deci, E.L. Intrinsic and extrinsic motivation from a self-determination theory perspective: Definitions, theory, practices, and future directions. Contemp. Educ. Psychol. 2020, 61, 101860. [CrossRef]

10. Vallerand, R.J.; Pelletier, L.G.; Koestner, R. Reflections on self-determination theory. Can. Psychol./Psychol. Can. 2008, 49, 257. [CrossRef]

11. Soenens, B.; Vansteenkiste, M. A theoretical upgrade of the concept of parental psychological control: Proposing new insights on the basis of self-determination theory. Dev. Rev. 2010, 30, 74-99. [CrossRef]

12. Reeve, J.; Halusic, M. How K-12 teachers can put self-determination theory principles into practice. Theory Res. Educ. 2009, 7, 145-154. [CrossRef]

13. Matosic, D.; Ntoumanis, N.; Quested, E. Antecedents of need supportive and controlling interpersonal styles from a selfdetermination theory perspective: A review and implications for sport psychology research. Sport Exerc. Psychol. Res. 2016, 145-180. [CrossRef]

14. Lam, S.F.; Law, W.; Chan, C.K.; Wong, B.P.; Zhang, X. A latent class growth analysis of school bullying and its social context: The self-determination theory perspective. Sch. Psychol. Q. 2015, 30, 75. [CrossRef] [PubMed]

15. Standage, M.; Duda, J.L.; Ntoumanis, N. A test of self-determination theory in school physical education. Br. J. Educ. Psychol. 2005, 75, 411-433. [CrossRef]

16. Ryan, R.M.; Deci, E.L. Self-Determination Theory: Basic Psychological Needs in Motivation, Development, and Wellness; Guilford Publications: New York, NY, USA, 2017.

17. Warburton, V.E.; Wang, J.C.; Bartholomew, K.J.; Tuff, R.L.; Bishop, K.C. Need satisfaction and need frustration as distinct and potentially co-occurring constructs: Need profiles examined in physical education and sport. Motiv. Emot. 2020, 44, 54-66. [CrossRef]

18. Trigueros, R.; Aguilar-Parra, J.M.; López-Liria, R.; Rocamora, P. The dark side of the self-determination theory and its influence on the emotional and cognitive processes of students in physical education. Int. J. Environ. Res. Public Health 2019, $16,4444$. [CrossRef]

19. Cronin, L.; Marchant, D.; Johnson, L.; Huntley, E.; Kosteli, M.C.; Varga, J.; Ellison, P. Life skills development in physical education: A self-determination theory-based investigation across the school term. Psychol. Sport Exerc. 2020, 49, 101711. [CrossRef]

20. Tinsley, B.J. How Children Learn to be Healthy; Cambridge University Press: Cambridge, UK, 2003.

21. Van Aart, I.; Hartman, E.; Elferink-Gemser, M.; Mombarg, R.; Visscher, C. Relations among basic psychological needs, PEmotivation and fundamental movement skills in 9-12-year-old boys and girls in Physical Education. Phys. Educ. Sport Pedagog. 2017, 22, 15-34. [CrossRef]

22. Patón, R.N.; Fernández, J.E.R.; Nemiña, R.E. Análisis de la satisfacción de las necesidades psicológicas básicas, motivación y disfrute en Educación Física en Primaria. Sportis: Revista Técnico-Científica del Deporte Escolar, Educación Física y Psicomotricidad 2016, 2, 439-455. [CrossRef]

23. Ajzen, I. Attitudes, Personality, and Behavior; Dorsey Press: Chicago, IL, USA, 1988. 
24. Ajzen, I. The theory of planned behavior. Organ. Behav. Hum. Decis. Process. 1991, 50, 179-211. [CrossRef]

25. Martin, J.J.; Kulinna, P.H. Self-efficacy theory and the theory of planned behavior: Teaching physically active physical education classes. Res. Q. Exerc. Sport 2004, 75, 288-297. [CrossRef] [PubMed]

26. Ries, F.; Hein, V.; Pihu, M.; Armenta, J.M.S. Self-identity as a component of the Theory of Planned Behaviour in predicting physical activity. Eur. Phys. Educ. Rev. 2012, 18, 322-334. [CrossRef]

27. Trigueros, R.; Aguilar-Parra, J.M.; Cangas, A.J.; Fernández-Batanero, J.M.; Álvarez, J.F. The influence of the social context on motivation towards the practice of physical activity and the intention to be physically active. Int. J. Environ. Res. Public Health 2019, 16, 4212. [CrossRef] [PubMed]

28. Wang, L.; Wang, M.; Wen, H. Teaching practice of physical education teachers for students with special needs: An application of the theory of planned behaviour. Int. J. Disabil. Dev. Educ. 2015, 62, 590-607. [CrossRef]

29. Lee, A.S.; Standage, M.; Hagger, M.S.; Chan, D.K. Applying the Trans-Contextual Model to Promote Sport Injury Prevention Behaviours among Secondary School Students. Scand. J. Med. Sci. Sports 2021. [CrossRef] [PubMed]

30. Hamilton, K.; van Dongen, A.; Hagger, M.S. An extended theory of planned behavior for parent-for-child health behaviors: A meta-analysis. Health Psychol. 2020, 10, 863. [CrossRef] [PubMed]

31. Huang, J.; Antonides, G.; Nie, F. Social-Psychological Factors in Food Consumption of Rural Residents: The Role of Perceived Need and Habit within the Theory of Planned Behavior. Nutrients 2020, 12, 1203. [CrossRef] [PubMed]

32. Hassandra, M.; Vlachopoulos, S.P.; Kosmidou, E.; Hatzigeorgiadis, A.; Goudas, M.; Theodorakis, Y. Predicting students' intention to smoke by theory of planned behaviour variables and parental influences across school grade levels. Psychol. Health 2011, 26, 1241-1258. [CrossRef]

33. Trigueros, R.; Mínguez, L.A.; González-Bernal, J.J.; Aguilar-Parra, J.M.; Padilla, D.; Álvarez, J.F. Validation of the Satisfaction Scale of Basic Psychological Needs in Physical Education with the Incorporation of the Novelty in the Spanish Context. Sustainability 2019, 11, 6250. [CrossRef]

34. Trigueros, R.; Maldonado, J.J.; Vicente, F.; González-Bernal, J.J.; Ortiz, L.; González-Santos, J. Adaptación y Validación Al Contexto de La Educación Fisica de La Escala de La Frustración de Las Necesidades Psicológicas En El Ejercicio Fisico Con La Inclusión de La Novedad Como Necesidad Psicológica. Rev. Psicol. Deporte 2020, 25, 295-303.

35. Trigueros, R.; Sicilia, A.; Alcaraz-Ibáñez, M.; Dumitru, D.C. Adaptación y validación española de la escala revisada del locus percibido de causalidad (PLOC-R) en educación física. Cuad. Psicol. Deporte 2017, 1, 25-32.

36. Serra-Majem, L.; Ribas, L.; Ngo, J.; Ortega, R.M.; Garcia, A.; Perez-Rodrigo, C.; Aranceta, J. Food, Youth and the Mediterranean Diet in Spain. Development of KIDMED, Mediterranean Diet Quality Index in children and adolescents. Public Health Nutr. 2004, 7, 931-935. [CrossRef] [PubMed]

37. Beauducel, A.; Herzberg, P.Y. On the performance of maximum likelihood versus means and variance adjusted weighted least squares estimation in CFA. Struct. Equ. Modeling 2006, 13, 186-203. [CrossRef]

38. Hayes, A.F.; Scharkow, M. The relative trustworthiness of inferential tests of the indirect effect in statistical mediation analysis: Does method really matter? Psychol. Sci. 2013, 24, 1918-1927. [CrossRef] [PubMed]

39. Marsh, H.W.; Hau, K.T.; Wen, Z. In search golden rules: Comment on hypothesis-testing approaches to setting cutoff values for fit indexes and dangers in overgeneralizing Hu and Bentler's (1999) findings. Struct. Equ. Model. 2004, 11, 320-341. [CrossRef]

40. Alexandr, A.; Sergij, T.; Olena, O. Role of physical education on the formation of a healthy lifestyle outside of school hours. $J$. Phys. Educ. Sport 2016, 16, 335.

41. Klein, E.; Hollingshead, A. Collaboration between special and physical education: The benefits of a healthy lifestyle for all students. Teach. Except. Child. 2015, 47, 163-171. [CrossRef]

42. Moore, R.C.; Cosco, N.G. Using behavior mapping to investigate healthy outdoor environments for children and families. Innov. Approaches Res. Excell. Landsc. Health 2010, 2, 33-72.

43. Costello, E.J.; Copeland, W.; Angold, A. Trends in psychopathology across the adolescent years: What changes when children become adolescents, and when adolescents become adults? J. Child Psychol. Psychiatry 2011, 52, 1015-1025. [CrossRef]

44. Cheon, S.H.; Reeve, J.; Yu, T.H.; Jang, H.R. The teacher benefits from giving autonomy support during physical education instruction. J. Sport Exerc. Psychol. 2014, 36, 331-346. [CrossRef]

45. How, Y.M.; Whipp, P.; Dimmock, J.; Jackson, B. The effects of choice on autonomous motivation, perceived autonomy support, and physical activity levels in high school physical education. J. Teach. Phys. 2013, 32, 131-148. [CrossRef]

46. Forbes, E.E.; Stepp, S.D.; Dahl, R.E.; Ryan, N.D.; Whalen, D.; Axelson, D.A.; Birmaher, B.; Silk, J.S. Real-world affect and social context as predictors of treatment response in child and adolescent depression and anxiety: An ecological momentary assessment study. J. Child Adolesc. Psychopharmacol. 2012, 22, 37-47. [CrossRef]

47. Trigueros, R.; Aguilar-Parra, J.M.; Cangas, A.J.; López-Liria, R.; Álvarez, J.F. Influence of physical education teachers on motivation, embarrassment and the intention of being physically active during adolescence. Int. J. Environ. Res. Public Health 2019, 16, 2295. [CrossRef]

48. Trigueros, R.; Cangas, A.J.; Aguilar-Parra, J.M.; Álvarez, J.F.; García-Más, A. No more bricks in the wall: Adopting healthy lifestyles through physical education classes. Int. J. Environ. Res. Public Health 2019, 16, 4860. [CrossRef] [PubMed]

49. Haerens, L.; Aelterman, N.; Vansteenkiste, M.; Soenens, B.; Van Petegem, S. Do perceived autonomy-supportive and controlling teaching relate to physical education students' motivational experiences through unique pathways? Distinguishing between the bright and dark side of motivation. Psychol. Sport Exerc. 2015, 16, 26-36. [CrossRef] 
50. Trigueros, R.; Navarro, N. La influencia del docente sobre la motivación, las estrategias de aprendizaje, pensamiento crítico de los estudiantes y rendimiento académico en el área de Educación Física. Psychol. Soc. Educ. 2019, 11, 137-150. [CrossRef]

51. Lirola, M.J.; Trigueros, R.; Aguilar-Parra, J.M.; Mercader, I.; Fernandez Campoy, J.M.; del Pilar Díaz-López, M. Physical Education and the Adoption of Habits Related to the Mediterranean Diet. Nutrients 2021, 13, 567. [CrossRef] [PubMed] 